\title{
Attitude, Parental Encouragement and Perception of the Importance of English in English Language Learning
}

\author{
Gopala Krishnan Sekharan Nair ${ }^{1}$, Roszainora Setia ${ }^{1}$, Razita Mohamad ${ }^{1}$, Zafri Bin Abdul Kadir ${ }^{2}$, Azyanee \\ Luqman $^{3}$, Thenmolli Vadeveloo ${ }^{4} \&$ Haslina Che $\mathrm{Ngah}^{5}$ \\ ${ }^{1}$ Academy of Language Studies, Universiti Teknologi MARA (UiTM) Dungun, Terengganu, Malaysia \\ ${ }^{2}$ Lot 2048, Padang Midin, 21400 Kuala Terengganu, Terengganu, Malaysia \\ ${ }^{3}$ Faculty of Business Management, Universiti Teknologi MARA, Dungun, Terengganu, Malaysia \\ ${ }^{4}$ Faculty of Administrative Science \& Policy Studies, Universiti Teknologi MARA, Dungun, Terengganu, \\ Malaysia \\ ${ }^{5}$ Faculty of Hotel \& Tourism Management, Universiti Teknologi MARA (UiTM) Dungun, Terengganu, \\ Malaysia
}

Correspondence: Gopala Krishnan Sekharan Nair, Academy of Language Studies, Universiti Teknologi MARA (UiTM) Dungun Campus, 23000 Dungun, Terengganu, Malaysia. E-mail: gopala@tganu.uitm.edu.my

Received: July 24, 2013 Accepted: December 8, 2013 Online Published: January 27, 2014

doi:10.5539/ass.v10n3p1 URL: http://dx.doi.org/10.5539/ass.v10n3p1

\begin{abstract}
This study investigated the students' perception of the importance of English language amongst a sample of 150 Upper Six students from a population of 755 students from six schools in the district of Marang, Terengganu. Also studied was whether their attitude towards learning English language is positive and whether they receive sufficient parental encouragement and support in their English language learning. It was found that the students were well aware of the importance of English language and also had a very positive attitude towards English Language learning. The parental encouragement and support scores also recorded a high total mean. In all three instances the sample means were well above the mid-point means indicating that the sample means fell in the higher halves of the mean scores. This implies that students are well aware of the importance of English language, are very positive about learning English language and receive more than adequate parental encouragement and support in their English language learning. Correlation analysis showed that there was a significant and positive relationship between the students' perception of the importance of English language and their attitude towards learning the language. Since the students' attitude and parental encouragement and support seem to be satisfactory, future researchers should investigate whether the curriculum offered is suitable for rural students.
\end{abstract}

Keywords: perception of importance, attitude, parental encouragement, importance of English, English language learning

\section{Introduction}

This study primarily focuses on the students' perception of the importance of English language and their attitude towards learning English language. Attitude, according to Spolsky (1989), fuels motivation which can enhance learning. However, the issues of motivation are beyond the scope of this study. This study checks upon the students' attitude towards English language learning only.

Roth (2008) mentioned that parental encouragement can shape the attitude of the students either positively or otherwise and also parental encouragement may have an effect on the motivational level of the students. This study investigates whether students receive adequate parental encouragement and support in their English language learning. How parental encouragement impacts on motivation is outside the scope of this study.

This study also investigated whether there was any significant relationship between students' perception of English and attitude towards learning English language. There are also other external variables such as suitability of curriculum and teaching styles in determining the attitude of the students. However these issues are not within the scope of this study. 
Being an international language, great emphasis is given to its teaching as a foreign or second language throughout the world (Emir, 2010). Malaysia is no exception. Pennycook (1994), pointed out that proficiency in an international language is a must for any country wishing to gain power and prestige.

Grubbs et al., (2009), stated that students from universities all over the world, even though English language is not their daily medium of communication, study in English to enable them to compete in the global economy. According to Abdel-Rahman (2009), English and Mandarin Chinese are the two most widely used languages today. With English language becoming more significant each day due to globalization and increasing competition among nations in the world, there has been a renewed effort by the relevant authorities to improve the standard of the language in the country (Faradila, 2010). One of them is the introduction of English literature into the English language syllabus in schools (Shamsudin, 2009). The results, though, have not been encouraging. After about 11 years of

learning English Language (excluding tertiary learning), Malaysian graduates are found to be still not proficient in the language (Nor Hashimah et al., 2008).

According to Spolsky (1969) attitude is regarded as one of the crucial elements that enables the learning of a second language such as English. He suggested that the rate of progress of acquiring a second language is enhanced or impeded by a positive attitude or a lack of it. This study attempted to find out whether students generally have a favourable perception on the importance of English language. Besides, the researcher also sought to determine whether the students generally had a positive disposition towards learning English language. According to Spolsky (1969) attitude is regarded as one of the crucial elements that enables the learning of a second language such as English. He suggested that the rate of progress of acquiring a second language is enhanced or impeded by a positive attitude or a lack of it.

This is among the reason why, the researcher sought to find out whether the students by and large had a positive inclination towards learning English language. Additionally the researcher also investigated whether the students received adequate parental encouragement and support towards learning English language. Subsequently the researcher studied whether there was any relationship between students' perception of the importance of English language and their attitude towards learning the language.

Also investigated in this study was the possibility of a relationship between parental encouragement and support that the students receive in English language learning and their attitude towards learning the language. Further, the researcher looked into there being the possibility of a relationship between the students' attitude towards learning English language and their English language performance. The researcher also carried out an analysis to determine whether the students' perception of the importance of English language had a relationship with their English language performance.

Descriptive analysis such as mean, median and mode was used to find out students' attitudinal orientations in research questions 1,2 and 3. Whereas, inferential statistics such as correlation was used to answer research questions 4 to 7 . Academicians and educationists have come up with numerous definitions and statements on attitude. Amongst them are:

Attitude is vital in learning and that it is attitude that fuels motivation (Gardner \& Lambert, 1972). Lifrieri (2005) emphasized that the right attitudes are necessary for effective language learning while Brown (2001), stated that Attitude is a manifestation of a person's favourable emotions and feelings towards something. For the purposes of this study, Browns (2001) definition of attitude would be adopted.

\subsection{Attitude towards Learning English Language}

Thang et al. (2011) found that the students have positive attitudes towards the learning of English if they realize the importance of English language in the school programme. They found that realization of the importance of English boosts attitude which in turn spurs the desire to learn the language.

Most of the researches on this issue have revealed that students' attitudes towards learning a second/foreign language is an integral part of learning and that it should be an essential component of second/foreign language learning pedagogy (Emir, 2010). People are more highly motivated, and consequently often more successful, in acquiring a second language when they feel positive towards those who use it (Holmes, 2008).

Many studies have been conducted within Europe itself to determine the attitude of students towards English. Lasagabaster (2003), in his study of Attitudes Towards English In The Basque Autonomous Community found that the students showed a very positive attitude in English language with a scale of almost 4 (out of 5 for very positive and 1 for very negative attitude). In Flanders, Belgium, Lasagabaster added, some people think that English language has become a threat to Dutch (Belgium's official language) especially with the ever increasing 
number of university courses being taught in English. He concluded that in the face of such a situation, it is imperative that students should have a positive attitude towards English language.

People in many parts of the world may have a positive attitude towards English language because of their high respect for the Westerners, especially the Americans and the British. Even the Japanese, the most advanced race in Asia and who think that Africans and other Asians are inferior, look up to Westerners, so much so that if an American comes to their place, all the Japanese want to meet him (Kobayashi, 2010).

English has spread even to the advanced nation of Federal Republic of Germany, Europe's most powerful and leading economy and the neighbouring country of Great Britain. Hilgendorf (2007) suggested that although there are numerous factors opposing the spread of English, including a lengthy history of negative attitudes towards foreign linguistic elements, in reality, judging from the extent to which English is used in society every day, the positive attitudes clearly succeed in overcoming whatever prejudices that society has towards learning English. Thus it is important that even students in Malaysia should have a positive attitude towards English language so that they may not be influenced by any antagonism towards the language by any sector of the society.

\subsection{Awareness of the Importance of English Language}

An awareness of the importance of English in the current setting can result in enhancing the students' attitude towards learning the language. In Macao, a former Portuguese colony, a study on university students' attitude towards English language and English language learning showed that the students are motivated English learners who recognize the importance of the language for the future development of Macao (Young, 2006). A second language may also be learned as a means to achieve some specific goals. For e.g. a second language is learned to get a good job, to travel, to use the language as a tool for further studies, or as a requirement for a degree (Taha, 2007).

\subsection{Parental Encouragement and Support}

In whatever learning that children are undertaking, parental involvement is always vital to ensure its success. There is some evidence that parental encouragement does help in motivating the child in performing better in English. Krishnan (2000) showed high correlation scores between parental encouragement, motivation and English language performance. The most important role of high school parents is to always offer encouragement, support and guidance to their children for they play a significant role in the progress of their offspring to be successful in their education, academic achievement, career and other accomplishments in life (Roth, 2008).

Parents can provide encouragement and support for their children in various ways. They do not have to be rich or wealthy to offer encouragement and support in their children's learning process. Zhou \& Glick (2005) suggested that parents who closely supervise and monitor how and when their adolescents spend their time or who their friends are, in fact are indirectly exerting influence and presenting encouragement to their children in their learning process.

\section{Problem Statement}

It is undisputed knowledge that English language is vital for an emerging economy like Malaysia. In fact Jayasankaran (1998) mentioned that most Foreign Direct Investors (FDIs) would prefer to invest in areas where communication in English is not a problem.

The researcher sought to find out whether in fact the students are aware of the importance of English language in this now globalized world. Additionally the researcher attempted to learn if the students are favourably disposed towards learning English language and whether they get any kind of support and encouragement from their parents in their English language learning. It is hoped that these findings would help teachers, school administrators and curriculum planners in implementing a more viable English language programme in rural areas such as the Marang district, Terengganu.

The research should benefit the teachers in their teaching of the language. In many rural parts of the country, English language is hardly spoken since almost $100 \%$ of the community consists of people of the same race or ethnicity. Furthermore, English language, to some sections of the populace is still very much related to colonialism, and hence is even considered unpatriotic to use. Templer (2003) referred to this situation as 'English as the language of the conqueror' to highlight the attitude and perception towards English language in relation to colonialism, imperialism and the relevant wars involving the Americans and British.

If the findings lead to better curriculum and better teaching, it will be beneficial to students in the future considering the policy of the majority of the public and private sectors which give preferences and advantages to candidates who have a good command of the English language when recruiting employees. 


\section{Method and Material}

The main objectives of the study are to ascertain whether the Upper Six students in the schools in the district of Marang, Terengganu do have a favourable perception on the importance of English language, a positive attitude towards learning the language and whether they receive adequate parental encouragement and support in the language learning. There is a direct correlation between the level of success in foreign language and the attitudes of learners towards foreign language (Emir, 2010).

A combination of self-developed and adopted questionnaire was constructed to collect the appropriate data, taking into consideration the objectives and research questions. The questionnaire was then pilot-tested before being applied to the actual sample of students.

\subsection{Questionaire}

The items posed in the questionnaire are a combination of self-developed items and those adapted from the questionnaire used by Abu-Ghazaleh \& Hijazi (2011) in their study on Jordanian Graduate and Undergraduate University Students' Attitudes towards the English Language. Section A, obtains information about respondents profile, whereas Section B would obtain information pertaining to Students' Perception of the Importance of English Language. While Section B would gather information about Student's Attitude towards Learning English Language. Section D would yield information about Parental Encouragement and Support in English Language Learning. The questionnaire was put to use after it returned a reliability score of 0.750 .

\subsection{Population and Sample}

In this study the population comprises all the Upper Six students in the Marang district of Terengganu state. There are 755 Upper Six students in the Marang district. Out of which, a sample of 150 respondents were randomly selected.

\section{Results}

\subsection{Respondent's Profile}

There are 98 females and 52 males in the sample of 150 students which comprise Upper Six students from six schools in Marang, Terengganu, Malaysia. The total population size is 755 students. The majority of the respondents are female students who constitute 65.3 per cent of the respondents, as compared to the males who represent only 34.7 per cent of the sample.

\subsection{Students' Perception of the Importance of English Language}

It can clearly be seen that all the items have a high mean, i.e., between 3.77 and 4.24, with the highest possible mean being 5. Thus the students' perception of the importance of English language may not be the cause of the unsatisfactory and declining standard of English among the students in the country.

\subsection{Students Attitude towards Learning English Language}

It is obvious from the scores that all the items have a high mean, i.e. between 3.63 and 4.20. This backs the view that the sample has a positive attitude towards learning English language regardless of their English language performance. This implies that the students' attitude towards learning English language is not the cause for the current situation as far as the standard of English language among students in Malaysia is concerned.

\subsection{Parental Encouragement and Support in Their English Language Learning}

It can clearly be seen that all the items have a high mean, i.e., between 3.17 and 3.69. This shows that almost all the students receive quite sufficient encouragement and support from their parents in their English language learning despite their English language performance. This signifies that the current state of affairs of English language among students in the Malaysia is not contributed by lack of parental encouragement and support that they receive.

\subsection{Relationship between the Students' Perception of the Importance of English Language and Their Attitude towards Learning English Language}

When the hypothesis for this relationship was tested, the Pearson $r$ value is 0.646 and the $p<0.05$. Therefore the researcher has to reject the null hypothesis and accept the alternative hypothesis.

There in fact exists a strong positive correlation between the students' perception of the importance of English and their attitude towards learning the language. 


\section{Discussion}

\subsection{Students' Perception of the Importance of English Language}

On the whole, the sample has a favourable perception of the importance of English language. Even though the students' perception of the importance of English language is satisfactory as far as the definition in this study is concerned, the findings show that the student's perception level still has room for improvement. A better mean would have displayed a more impressive and satisfying result to show the level of perception that these rural students have of English language in comparison with their counterparts in the urban parts of the country.

Overall we can say that the students in the sample do have a very positive perception of the importance of English language. A positive attitude towards learning English language would create a student who has a will to learn the language and thereby make more progress in learning than those who do not have such a positive attitude (Emir, 2010).

Holmes (2008) stated that people are more highly motivated, and consequently often more successful, in acquiring a second language when they feel positive towards learning English language and towards those who use it. Teachers should not resort to the common excuse of disinterested students in explaining dismal English language performances (Krishnan, 2000).

Gömleksiz (2010) stated that students' belief system is vital in shaping the outcome of their learning. He recommended that teachers should not only be teachers but salespersons who would promote the merit of their wares before attempting to ask students to master it. Thus all teachers should not just concentrate on the teaching but always be mindful of whether students are sufficiently informed of the importance of what they are learning.

According to Lennartsson, putting the blame on the students will only worsen the situation as it would give them unnecessary and additional pressure in their attempt to be proficient in English language, if they do not have a deep-rooted belief in the importance of what they are doing (Gömleksiz, 2010).

\subsection{Students Attitude towards Learning English Language}

On the whole, the sample has a positive attitude towards learning English language, as far as the definition of positive attitude in the study is concerned. As with perception, the mean value for the students' attitude too has some room for improvement. A higher mean value seems achievable if the relevant authorities are willing to put in some extra effort in determining the cause of the students' unsatisfactory performance in their English language lessons.

In any case, it is heartening to know that even students from a relatively rural area such as Marang do have a strong positive attitude towards learning English language. The value of a positive attitude was stressed by Spolsky (1969) who regarded attitude as one of the vital factors in the learning of a second language such as English. According to him the rate of progress of acquiring a second language is enhanced or impeded by a positive attitude or a lack of it. Indeed, Spolsky appeared to have placed much emphasis on learner readiness in the success of the learning of any skill. He said if the learner has an open mind and a keen interest in acquiring the second language, he will be more inclined to learn, have high motivation and would complement the teacher's teaching by his own efforts thereby accelerating his rate of learning.

It is imperative for students to have the right attitude towards learning English language in order for the learning process to take place smoothly and effectively. A positive attitude will bring about a more motivated and enthusiastic student to participate in the learning activities. Many studies have produced parallel results regarding the significance of having a positive attitude with regard to learning English language. When the students develop a positive attitude or self-confidence, they can then be persuaded to take part in classroom activities, and, thus, learning can be facilitated (Mirici, 2010). This is also in line with Young (2006) who suggested that learners' positive attitudes may lead to increased motivation, which, in turn, may lead to successful attainment of proficiency due to increased input and interaction.

\subsection{Parental Encouragement and Support in Their English Language Learning}

Overall, the respondents do receive adequate encouragement and support from their parents in their English language learning. Compared with the total mean scores for students' perception and attitude, the total mean score for parental encouragement and support allow even more room for improvement considering the maximum possible score of 60 . A higher mean score would have been obtainable had the study been conducted in some urban settings involving students of highly educated parents especially those of non-Malay ethnicities. According to Spolsky (1989), students' coming from backgrounds of higher socio-economic status had comparatively more parental encouragement and generally performed better in English than their counterparts of 
lower socio-economic backgrounds.

Thus, as far as this sample is concerned, the students are aware of the importance of English language and have a rather positive attitude towards learning the language. The analysis of their parental incomes shows that many of them come from the lower strata of society. Even if their parents are not wealthy and not highly educated, it is very encouraging to see that the parents themselves are aware of the importance of English language, do give their children encouragement and support in the language learning and must naturally have the desire to see their children excel in the language. Parents who take a serious interest in their children's learning process play a significant role in the latter's development and success in school or college, career and life endeavours (Roth, 2008).

There exists a strong positive correlation between the students' perception of the importance of English language and their attitude towards learning the language. When the students' are aware of the importance of English language, they are bound to have a positive attitude towards learning the language. The higher their degree of awareness or the more favourable their perception of the importance of English language is, the more positive their attitude towards learning the language would be.

Among others the findings above are in accordance with those of Thang et al. (2011) who found that the students have positive attitudes towards the learning of English language if they realize the importance of the language in the school programme. They further found that realization of the importance of English language boosts attitude which in turn spurs the desire to learn the language.

Teachers should point out to students how English language is important for the economy and improved economy would contribute to better quality of life for everyone in the nation. Shamsudin, (2009) pointed out that Foreign Direct Investors favoured nations where the populace was conversant in English as an English speaking populace is more easily trained than a non-English speaking one. Grubbs et al. (2009) in outlining the importance of English language in the era of globalization did also point out that in many countries wage earners more proficient in English, on the average, earn higher wages.

\section{Conclusion and Recommendations}

The study gives an indication that despite the students' low achievement in their English language performance, they are not lacking in their perception of the importance of the language, in their attitude towards learning the language and in the parental encouragement and support that they receive in the language learning. The findings seem to suggest that there are still areas which can be improved upon with respect to teaching effectiveness and course content suitability.

The authorities in the education departments of the Ministry of Education and the Ministry of Higher Learning should look into these matter and efforts should be undertaken to remedy the situation. The policy planners, curriculum designers, academicians, educationists and English language teachers and lecturers in school should take the necessary measures to improve the state of affairs of English language amongst students from the rural parts of the country.

Poor proficiency scores can be attributed to lack of parental encouragement. In fact, as mentioned earlier, Carhill et al. (2008), suggested that learners' age, parental education and parental English language proficiency, exposure and school quality are amongst the main factors that contribute to learners English language performance. Currently 50 English teaching assistants from the The Fulbright English Teaching Assistantship (ETA) programme, U.S.A. are serving schools in Terengganu, Pahang and Johor. When they leave in November they will be replaced by 75 new participants early next year (The Star, May 27). This number should be increased further to meet the growing needs of the rural students to learn English language more effectively.

Students' attitude towards learning English language should be checked regularly to ensure that they remain enthusiastic and motivated to learn in spite of their performance and results. If their attitude and situation are left unchecked, there is a possibility they will soon fall behind in their language learning when they feel that they have too much to catch-up. Finally, their interest to learn the language may diminish even further.

\section{References}

Abdel-Rahman, A. (2009). Attitudes of Jordanian College Students towards Learning English as a Foreign Language. College Student Journal, 43(2). Retrieved January 3, 2012, from http://web.ebscohost.com/ehost/detail?sid=15742565-cba2-42ba-b431

Abu-Ghazaleh, D., \& Hijazi, D. (2011). Jordanian Graduate and Undergraduate University Students' Attitudes towards the English Language. European Journal of Social Sciences, 21(4). Retrieved January 7, 2012, 
from http://www.eurojournals.com/EJSS_21_4_12.pdf

Brown, H. D. (2001). Teaching by Principles: An Interactive Approach to Language Pedagogy. San Francisco Public University.

Carhill, A., Suárez-Orozco, C., \& Mariela Páez, M. (2008). Explaining English Language Proficiency among Adolescent Immigrant Students. American Educational Research Journal. http://dx.doi.org/10.3102/0002831208321443

Emir, S. E. (2010). A Study on the Affective Attitudes of Students at Gazi Educational Faculty towards English Classes. Ekev Akademi DergisiI Yll: 14 Sayl: 45 (Güz 2010) 129. Retrieved January 3, 2012, from http://web.ebscohost.com/ehost/pdfviewer/pdfviewer?sid=4cc28198-74e7-4787-909b-4447058a86cc\%40se ssionmgr $111 \&$ vid $=1 \&$ hid $=113$

Faradilla, E. (2010). Attitude towards Use of ICT and Its Actual Level of Use in English Language Teaching in Miri, Sarawak.

Gardner, R. C., \& Lambert, W. E. (1972). Attitudes and Motivations in Second Language Learning. Rowley, Massachusetts: Newbury House.

Gömleksiz, M. N. (2010). An Evaluation of Students' Attitudes toward English Language Learning in Terms of Several Variables. Procedia Social and Behavioral Sciences, 9, 913-918. http://dx.doi.org/10.1016/j.sbspro.2010.12.258

Grubbs, S. J., Chaengploy, S., \& Worawong, K. (2009). Rajabhat and Traditional Universities: Institutional Differences in Thai Students' Perceptions of English. High Educ., 57, 283-298. Retrieved January 3, 2012, from http://web.ebscohost.com/ehost/pdfviewer/pdfviewer?sid=e7921646-b278-44ed-b584-8e1dbfd86bb7\%40se ssionmgr15\&vid=1\&hid=9 http://dx.doi.org/10.1007/s10734-008-9144-2

Hilgendorf, S. (2007). English in Germany: Contact, Spread and Attitudes. World English, 26(2), 131-148. $\begin{array}{llll}\text { Retrieved January 3, 2012, from } & \text { 3, }\end{array}$ http://web.ebscohost.com/ehost/pdfviewer/pdfviewer?sid=271c5d8b-46b4-43ec-a2c0-9422578199ab\%40se ssionmgr113\&vid=1\&hid=113 http://dx.doi.org/10.1111/j.1467-971X.2007.00498.x

Holmes, J. (2008). An Introduction to Sociolinguistics. Learning about Language (3rd ed.). Pearson Education Limited.

Jala, I. (2010). On the Malaysian Economy, New Straits Times, May 28.

Jalaluddin, N. H., Awal, N. M., \& Bakar, K. A. (2008). The Mastery of English Language among Lower Secondary School Students in Malaysia: A Linguistic Analysis. European Journal of Social Sciences, 7(2).

Jayasankaran, S. (1998, December 10). The Multinationals and Language: Far Eastern Economic Review.

Kobayashi, Y. (2010). Discriminatory Attitudes toward Intercultural Communication in Domestic and Overseas Contexts. High Educ., 59, 323-333. Retrieved January 3, 2012, from http://web.ebscohost.com/ehost/pdfviewer/pdfviewer?sid=2359ca7d-d1dd-4e53-9f6d-419fd30f10da\%40ses sionmgr104\&vid=1\&hid=113 http://dx.doi.org/10.1007/s10734-009-9250-9

Krishnan, G. (2000). Home Environment and Motivational Orientation in Learning English as a Second Language: A Survey among the Sixth Form Students. Unpublished Academic Study, Universiti Sains Malaysia.

Lasagabaster, D. (2003). Attitudes towards English in the Basque Autonomous Community. World Englishes, 22(4). Retrieved January 3, 2012, from http://web.ebscohost.com/ehost/pdfviewer/pdfviewer?sid=26f2a5f4-437b-42be-adcc-1399dbc72a88\%40ses sionmgr115\&vid=1\&hid=113 http://dx.doi.org/10.1111/j.1467-971X.2003.00325.x

Lifrieri, V. (2005). A sociological perspective on motivation to learn EFL: The Case of Escuelas Plurilingües in Argentina. M.A thesis, University of Pittsburgh.

Mirici, I. H. (2010). Influence of Prestudy on Foreign Language Learning Attitude. Social Behavior and Personality, 38(2), 187-196. Retrieved January 3, 2012, from http://web.ebscohost.com/ehost/pdfviewer/pdfviewer?sid=e1d53825-0ace-4bdc-ab1c-002fca40b663\%40ses sionmgr112\&vid=1\&hid=113 http://dx.doi.org/10.2224/sbp.2010.38.2.187

Pennycook, A. (1994). The Cultural Politics of English as an International Language. London: Longman. 
Roth, B. (2008). The Importance of Parental Encouragement and Support. Retrieved April 20, 2012, from http://ezinearticles.com/?The-Importance-of-Parental-Encouragement-andSupport\&id=1622042

Shamsudin, A. (2009). Teaching Effectiveness and Course Content Suitability- A Survey among KPLI English Language Trainees at The Kuala Terengganu. Unpublished Academic Study, Universiti Teknologi MARA.

Spolsky, B. (1989). Conditions for Second Language Learning. Oxford: OUP.

Taha, T. A. (2007). Arabic as "A Critical-Need" Foreign Language in Post-9/11Era: A Study of Students' Attitudes and Motivation. Journal of Instructional Psychology, 34(3). Retrieved January 3, 2012, from http://web.ebscohost.com/ehost/pdfviewer/pdfviewer?sid=1c589ea0-46ca-4cfb-9851$0578488625 \mathrm{~cd} \% 40$ sessionmgr112\&vid=1\&hid $=113$

Templer, B. (2003). Teaching the Language of the Conqueror. Z Magazine Online. Retrieved April 19, 2012, from http://www.zcommunications.org/teaching-the-language-of-the-conqueror-by-bill-templer

Thang, S. M., Ting, S. L., \& Nurjanah, M. J. (2011). Attitudes and Motivation of Malaysian Secondary Students towards Learning English as a Second Language: A Case Study. 3L: The Southeast Asian Journal of English Language Studies, 17(1), 40-54. Retrieved January 7, 2012, from http://www.ukm.my/ppbl/3L/3L\%20vol\%2017\%20(1)\%202011/Vol\%2017(1)Full\%20Papers.\%20pdf/5.\% 203LVol17(1)2011Thang\%20Siew\%20Ming\%20et\%20al\%20doc.pdf

Young, M. Y. C. (2006). Macao Students' Attitudes toward English: A post-1999 Survey. World Englishes, 25(3-4), 479-490. Retrieved January 3, 2012, from http://web.ebscohost.com/ehost/pdfviewer/pdfviewer?sid=d04ddd50-8a8c-4632-835c-5afb9491a690\%40se ssionmgr111\&vid=1\&hid=113 http://dx.doi.org/10.1111/j.1467-971X.2006.00468.x

Zhou, Y., \& Glick, J. (2005). Encouragement for Educational Aspirations: The Role of Parents, Peers and Counselors When Explaining Group Differences. Retrieved April 21, 2012, from http://paa2005.princeton.edu/download.aspx?submissionId=50642

\section{Copyrights}

Copyright for this article is retained by the author(s), with first publication rights granted to the journal.

This is an open-access article distributed under the terms and conditions of the Creative Commons Attribution license (http://creativecommons.org/licenses/by/3.0/). 